\title{
Impact of Sett Disinfectants on Yellow Leaf Disease (YLD) Incidence and Yield and Growth Parameters in Sugarcane
}

\author{
Suresh Madugula ${ }^{1 *}$, G. Uma Devi ${ }^{2}$, D. Adilakshmi ${ }^{1}$, N. Raja Kumar ${ }^{1}$, K. Vijayalakshmi ${ }^{3}$, M. Bharatalakshmi ${ }^{1}$ and \\ B. V. Bhaskara Reddy ${ }^{4}$
}

${ }^{1}$ Dept. of Plant Pathology, ${ }^{4}$ Institute of Frontier Technology, Regional Agricultural Research Station, Tirupathi, ANGRAU, Andhra Pradesh (531 001), India

${ }^{2}$ Dept. of Plant Pathology, College of Agriculture, ${ }^{3}$ National Institute of Plant Health Management (NIPHM), Rajendranagar, Hyderabad, Telangana (500 030), India

\section{Article History}

Manuscript No. AR1637

Received in $10^{\text {th }}$ July, 2016

Received in revised form $4^{\text {th }}$ August, 2016

Accepted in final form $7^{\text {th }}$ August, 2016

\section{Correspondence to}

"E-mail: sureshiari@yahoo.co.in

\section{Keywords}

Sugarcane, yellow leaf, juice quality, yield, DAS-ELISA

\begin{abstract}
Yellow leaf disease (YLD) of sugarcane caused by sugarcane yellow leaf virus (SCYLV), a Polerovirus of the Luteoviridae family is becoming a major threat to sugarcane cultivation in north coastal region of Andhra Pradesh state. As YLD is mainly transmitted through sett borne inoculum, the present study was carried out to evaluate the efficacy of some disinfectants on the reduction of inoculum load through sett treatment and confirmed by DAS-ELISA. Further, their impact on cane growth, yield and juice quality parameters were observed. From the present study it was found that even though there was slight increase in the number of clumps with TSP treatment at various doses compared to infected canes it was not significantly different from the other disinfectant chemicals and healthy canes proved to more effective in reducing the incidence levels than the sett treatments. Further, healthy canes resulted in lowest disease incidence compared to all the sett disinfection treatments which were significantly at par with each other. Present study also revealed that the sett disinfection chemicals did not have any effect on the yield and juice quality parameters of sugarcane. Whereas, healthy canes proved as the best management option for YLD with reduced disease incidence resulting in increased number of millable canes (NMC) and cane yields with higher juice quality values, especially in ratoon, emphasizing the role of healthy planting material for the effective management of YLD in field conditions.
\end{abstract}

\section{Introduction}

Sugarcane occupies a very prominent position in Indian agriculture and in the country's economy. India is the second largest producer of sugarcane followed by Brazil and it produces $300 \mathrm{mt}$ of cane year ${ }^{-1}$. Yellow Leaf Disease (YLD) in sugarcane earlier described as Yellow Leaf Syndrome (YLS) is characterized by a yellowing of the midrib and lamina is prevalent in most of the sugarcane growing countries including India. The disease is caused by Sugarcane Yellow Leaf Virus (SCYLV), a Polerovirus of the Luteoviridae family was first reported in Hawaii in the late 1980s (Schenck et al., 1997) and later in more than 30 countries. SCYLV often persists in the plants without being noticed in the field and it was observed that this non symptomatic stage seems to be the most common epidemiological state for this viral pathogen. In India, the disease was first reported during 1999 and the disease is widely distributed in most of the sugarcane growing regions of the country and the disease intensity was recorded up to $100 \%$ in certain susceptible varieties (Rao et al., 2001; Viswanathan et al., 1999). In the state of Andhra Pradesh, the disease is becoming a major threat to the sugarcane cultivation due to its wide spread and difficulty in diagnosis at field level by farming community. YLD incidence levels were observed as high as $60 \%$ in different sugarcane growing pockets of both Andhra Pradesh and Telangana districts irrespective of the varieties (Rajkumar and Suresh, 2014).

There is profound need for the management of the disease as the disease profoundly affects the yield and quality parameters of sugarcane (Viswanathan et al., 2014; Vega et al., 1997). As the disease primarily spreads through infected setts, to manage the disease, planting disease-free planting-materials indexed through sensitive diagnostic methods is essential. In view of 
the sett borne nature of SCYLV the present study is taken up to study the effect of some seed disinfection chemicals on the disease incidence, if any, and also to study the impact of these treatments on cane growth, yield and juice quality parameters in comparision with healthy cane material.

\section{Materials and Methods}

\subsection{Field experiment on evaluation of different sett disinfection treatments}

The present investigation was conducted at the Regional Agriculture Research Station, Anakapalle, Visakhapatnam District of Andhra Pradesh, India, situated at an altitude of $6.0 \mathrm{~m}$ above mean sea level, $12^{\circ} 14^{\prime}$ to $19^{\circ} 54^{\prime} \mathrm{N}$ latitude and $80^{\circ} 50^{\prime}$ to $84^{\circ} 50^{\prime} \mathrm{E}$ longitude, during 2014-15 and 2015-16 cropping season. The soils are clay loam, with low in available nitrogen $\left(215 \mathrm{~kg} \mathrm{~N} \mathrm{ha}^{-1}\right)$ and high in available phosphorus (35-45 $\left.\mathrm{kg} \mathrm{P}_{2} \mathrm{O}_{5} \mathrm{ha}^{-1}\right)$ and potassium $\left(510 \mathrm{~kg} \mathrm{~K}_{2} \mathrm{O} \mathrm{ha}^{-1}\right)$. Organic carbon content of the soil is medium $(0.65 \%)$. pH of the soil is 7.62 while the electrical conductivity of the soil is 0.26 $\mathrm{ds}^{-1}$. The total rainfall received in crop season $2014-15$ is $1009.8 \mathrm{~mm}$ in 54 rainy days and for $2015-16$ is $1340.9 \mathrm{~mm}$ in 64 rainy days.

Sugarcane variety 2001A 63 with minimum YLD grade of 1 was planted in RARS, Anakapalle farm along with disease free seedlings of the same variety as check with ten different sett disinfection treatments with Tri sodium ortho phosphate (TSP @ 5, 10 and 15\%), sterile water, 70\% ethanol, YLD infected sap and Sodium chloride ( $\mathrm{NaCl} @ 3$ and 6\%) along with healthy and infected canes as checks. Three budded setts were dipped in the disinfecting agents for 10 minutes in separate tubs and were planted immediately in the trenches each in four rows of $5 \mathrm{~m}$ each with three replications. Evaluation was carried out during the crop seasons of 2014-15 (plant) and 2015-16 (ratoon) in a Randomized Block Design (RBD) with three replications.

\subsection{DAS-ELISA}

DAS-ELISA was carried out using the kit obtained from M/s. AC Diagnostics, USA (Code-V093-K1). The plates were first coated with coating antibody supplied with the kit (diluted with coating buffer in 1:10 dilution) @ $100 \mu \mathrm{l}$ per well, covered tightly and incubated for $4 \mathrm{hrs}$ at room temperature i.e. 21-24 ${ }^{\circ} \mathrm{C}(\mathrm{RT})$ in a humid box. In the second step, wells are coated with $100 \mu \mathrm{l}$ of the leaf extract/stem sap duly preparing the loading diagram along with positive and negative control. The plate was incubated at $4{ }^{\circ} \mathrm{C}$ overnight at for the binding of the antigen on the plate walls in a humid box. The enzyme conjugate was prepared just before use by diluting 1000 times in conjugate buffer and coated to the wells @ $100 \mu \mathrm{l}$ each and incubated at RT for 2.5 hours. In the final step Para Nitro Phenol (PNP) substrate was added to the wells $100 \mu$ leach and incubated at RT in dark for 30 to 60 minutes and observed for colour development. After each step, the wells are emptied and washed thoroughly with PBST washing buffer for 4-6 times. Observations were taken visually and the colour change was observed photometrically at $405 \mathrm{~nm}$ using thermofischer scientific Multiscan- X, ELISA reader and the readings were documented.

\subsection{Collection of data}

Observations were recorded on net plot basis viz., number of clumps and tillers at $90 \mathrm{DAP} \mathrm{plot}^{-1}$, number of infected clumps and percent YLD incidence, SPAD Chlorophyll reading at 240 DAP, number of millable canes plot $^{-1}$, brix per cent, sucrose per cent, purity per cent, Commercial Cane Sucrose (CCS) per cent, Cane Length $(\mathrm{cm})$, Cane Diameter $(\mathrm{cm})$, single cane weight $(\mathrm{kg})$, cane yield $\left(\mathrm{t} \mathrm{ha}^{-1}\right)$ at harvest and CCS yield following the standard procedures.

\subsubsection{Yield components}

Number of sugarcane clumps was recorded along with the number of tillers per each clump in all the three replications and the mean calculated. Number of infected clumps was recorded showing visible YLD symptoms starting from the first appearance of the symptoms in each plot. Percent YLD incidence was calculated as shown below:

$$
\begin{aligned}
& \text { Number of clumps with } \\
& \% \text { YLD incidence }=\frac{\text { YLD symptoms }}{\text { Total number of clumps plot }{ }^{-1}} \times 100
\end{aligned}
$$

The length of ten randomly selected mature millable canes was measured from the base to the least transverse mark at the time of harvesting and reported as mean length in metres. Cane diameter was measured perpendicular to bud at the midpoint of cane half way between two nodes with the help of vernier callipers and the mean data was expressed in centimetres. Three tagged canes from each treatment were weighed using digital balance and the average weight was recorded and expressed in $\mathrm{kg}$. The fully developed cane with a minimum height of one meter was considered as millable cane. Number of millable canes plot ${ }^{-1}$ was counted at harvest. All the millable canes were harvested at ground level individually at around ten months age of crop. The weight of canes in $\mathrm{kg} \mathrm{net}^{-1}$ plot was recorded after detrashing and de-topping just below the spindle using the Avery platform balance and expressed in tonnes. Number of internodes was recorded from three tagged canes at the time of harvesting for each treatment using a scale and the mean of three replications was recorded. Internode length calculated as a.

Internode length $(\mathrm{cm})=$ Average cane height $(\mathrm{cm}) /$ Average 
number of internodes.

\subsubsection{Juice quality parameters}

Juice analysis was carried out prior to harvesting in the Department of Soil Science, RARS, Anakapalle. Juice parameters i.e. Brix, juice sucrose, Purity was estimated in a filtered juice by using Saccharimeter (MCP 5000 Sucromat) and Refractometer (MCP 550 Abbemet) as per the method suggested by Meade and Chen (1971).

\subsubsection{SPAD chlorophyll meter reading}

The total leaf chlorophyll content was measured with SPAD (Soil Plant Analytical Development) Chlorophyll meter Reading (SCMR) using SPAD 502 chlorophyll metre (Konica Minolta) following method of Turner and Jund (1991) at the time of juice analysis during 2015-16 season in six different cultivars.

\subsubsection{Statistical analysis}

The experimental data was statistically analysed using OPSTAT software using pairwise t test using the mean value for each parameter of the three replications under each treatment. $P$ values $<0.05$ were considered as statistically significant.

\section{Results and Discussion}

\subsection{Evaluation of sett disinfection chemicals for the reduction of YLD incidence}

Results of different sett disinfection treatments on the YLD incidence both in plant and ratoon crops was presented in Table 1. Among the different sett disinfection treatments highest number of clumps was observed in plots planted with healthy canes in both plant (31.3) and ratoon (29.3) followed by Trisodium Ortho Phosphate (TSP) @ 20\% treated plots (28.3 in plant and 26.0 in ratoon). Sterile water $\left(\mathrm{T}_{4}\right)$ and YLD infected sap dip $\left(\mathrm{T}_{6}\right)$ treated plots resulted in 28.0 clumps each in plant crop and 24.3 and 24.7 clumps respectively in ratoon crop. Plots planted with setts treated with Sodium chloride $(\mathrm{NaCl})$ (a) 3\% and 6\% showed 27.3 and 26.7 clumps in plant and 24.3 and 24 clumps in ratoon respectively. Plots planted with Ethanol $70 \%$ treated setts had mean clumps of 24.3 and 22.3 in plant and ratoon crop respectively. Least number of clumps was seen in plots planted with YLD infected setts both in plant (22.0) and ratoon (18.0) crops. Statistical analysis showed that the treatment effect was non-significant for the number of clumps and all the treatments are statistically at par. The mean number of infected clumps with different sett treatments varied significantly with the healthy canes but is statistically at par among the different sett disinfection treatments. Healthy canes resulted in least YLD incidence both in plant $(0.0 \%)$ and ratoon $(5.7 \%)$ crops with lowest YLD infected clumps (0 and 1.7 in plant and ratoon crops respectively) in comparision with the plots with infected setts having 33.3\% YLD incidence with 7.7 mean infected clumps in plant and $50 \%$ incidence with 9.0 mean infected clumps in ratoon. Among the TSP sett treatments TSP@10\% resulted in lowest YLD incidence with 25.3 and $31.1 \%$ in plant and ratoon crops followed by TSP@5\% with $27.2 \%$ and $33.8 \%$ incidence in plant and ratoon crops having 7.3 and 8.3 infected clumps in plant and ratoon respectively and TSP@20\% showing 28.2\% and 37.2\% YLD incidence both in plant and ratoon crops ( 8.0 and 9.7 infected clumps) which are statistically not different from one another. $\mathrm{NaCl}$ treatments showed $10.3 \%$ and $31.7 \%$ incidence at $3 \%$ dose in

\begin{tabular}{|c|c|c|c|c|c|c|c|c|c|}
\hline \multirow[t]{2}{*}{$\begin{array}{l}\text { Sl. } \\
\text { No. }\end{array}$} & \multirow[t]{2}{*}{ Treatment } & \multicolumn{2}{|c|}{ No of clumps } & \multicolumn{2}{|c|}{$\begin{array}{c}\text { YLD infected } \\
\text { clumps } \\
\end{array}$} & \multicolumn{2}{|c|}{$\begin{array}{l}\text { Percent YLD } \\
\text { infection }\end{array}$} & \multicolumn{2}{|c|}{ Percent reduction } \\
\hline & & Plant & Ratoon & Plant & Ratoon & Plant & Ratoon & Plant & Ratoon \\
\hline $\mathrm{T}_{1}$ & Trisodium ortho phosphate (TSP) $5 \%$ & 27.0 & 24.7 & 7.3 & 8.3 & 27.2 & 33.8 & 18.4 & 32.4 \\
\hline $\mathrm{T}_{2}$ & Trisodium ortho phosphate (TSP) $10 \%$ & 26.3 & 24.7 & 6.7 & 7.7 & 25.3 & 31.1 & 24.0 & 37.8 \\
\hline $\mathrm{T}_{3}$ & Trisodium ortho phosphate (TSP) $20 \%$ & 28.3 & 26.0 & 8.0 & 9.7 & 28.2 & 37.2 & 15.2 & 25.6 \\
\hline $\mathrm{T}_{4}$ & Sterile water & 28.0 & 24.3 & 9.0 & 11.0 & 32.1 & 45.2 & 3.5 & 9.6 \\
\hline $\mathrm{T}_{5}$ & Ethanol $70 \%$ & 24.3 & 22.3 & 7.7 & 9.3 & 31.5 & 41.8 & 5.4 & 16.4 \\
\hline $\mathrm{T}_{6}$ & YLD infected sap dip & 28.0 & 24.7 & 8.0 & 9.7 & 28.6 & 39.2 & 14.2 & 21.6 \\
\hline $\mathrm{T}_{7}$ & Healthy canes & 31.3 & 29.3 & 0.0 & 1.7 & 0.0 & 5.7 & 100.0 & 88.6 \\
\hline $\mathrm{T}_{8}$ & Sodium chloride $(\mathrm{NaCl}) 3 \%$ & 27.3 & 24.3 & 8.7 & 10.3 & 31.7 & 42.5 & 4.8 & 15.1 \\
\hline $\mathrm{T}_{9}$ & Sodium chloride $(\mathrm{NaCl}) 6 \%$ & 26.7 & 24.0 & 7.7 & 9.3 & 28.8 & 38.9 & 13.7 & 22.2 \\
\hline \multirow[t]{3}{*}{$\mathrm{T}_{10}$} & YLD infected canes & 22.0 & 18.0 & 7.3 & 9.0 & 33.3 & 50.0 & 0.0 & 0.0 \\
\hline & $\mathrm{SEm} \pm$ & 2.230 & 1.775 & 1.313 & 1.267 & & & & \\
\hline & $\mathrm{CD}(p=0.05)$ & N/A & 5.316 & 3.92 & 3.795 & & & & \\
\hline
\end{tabular}


plant and ratoon crops respectively with 8.7 and 10.3 mean infected clumps. At 6\%, the mean incidence levels are lower with $28.8 \%$ in plant and $38.9 \%$ in ratoon which are statistically at par with the other sett disinfection treatments.

Healthy canes planted plots resulted in highest YLD reduction with $100 \%$ in plant and $88.6 \%$ in ratoon in comparision with infected setts. Among the different sett disinfection treatments TSP $10 \%$ resulted in highest per cent reduction of $24 \%$ in plant and 37.8\% reduction in ratoon followed by TSP @ 5\% (18.4\% in plant and 32.4\% in ratoon) and TSP @ 20\% (15.2\% and $25.6 \%$ reduction in plant and ratoon respectively). $\mathrm{NaCl}$ sett treatment @6\% resulted in 13.7\% and 22.2\% reduction, while at $3 \%$ the percent reduction is less with only $4.8 \%$ and $15.1 \%$. Sterile water and Ethanol treatments were found least effective with $3.5 \%$ and $5.4 \%$ reduction in plant and $9.6 \%$ and $16.4 \%$ reduction in ratoon. Earlier some studies were aimed at eradication seed borne viral inoculum using different seed disinfection treatments (Cordoba-Selles et al., 2007; Lewandowski and Hayes, 2010). Lewandowski and Hayes (2010) tested two different forms of Tri Sodium Phosphate (TSP) and reported that TSP with sodium carbonate was more effective in eliminating Tobacco Mosaic Virus (TMV) compared to TSP with sodium sesquicarbonate. Cordoba-Selles et al. (2007) reported that the seed borne inoculum of Pepino Mosaic Virus (PepMV) in tomato seeds can be effectively by immersion in 10\% TSP for $3 \mathrm{hrs}$ which also favours good germination. As YLD is mainly transmitted through sett borne inoculum, the present study was carried out to evaluate the efficacy of some disinfectant chemicals on the reduction of inoculum load through sett treatment. Thus from the present study it can be inferred that seed disinfection chemicals were not effective in reducing the YLD incidence levels in comparison with healthy canes.

\subsection{Efficacy of sett disinfection treatments on cane growth and yield parameters}

The results on the effect of different sett disinfection treatments on the different yield factors like cane length, cane weight; number of millable canes and yield was given in Table 2. In healthy cane planted plots cane length $(2.15 \mathrm{mt}$ in plant and 2.12 in ratoon), cane weight (1.14 kg in both plant and ratoon) were highest. TSP sett treatment resulted in cane lengths in the range of 1.68 to $2.00 \mathrm{mt}$ in plant and 1.83 to $1.89 \mathrm{mt}$ in ratoon crop at different doses which are statistically at par with each other. Similar trend was observed with rest of the sett disinfection treatments pertaining to cane length which are statistically not significant. Individual cane weight also not significantly varied among the different treatments with healthy canes planted plots showing highest mean cane weight of 1.14 $\mathrm{kg}$ both in plant and ratoon crops compared to infected canes (1.04 kg in plant and $1.17 \mathrm{~kg}$ in ratoon) which are statistically not significant. Whereas the cane weight ranged between 0.96 $\mathrm{kg}$ to $1.19 \mathrm{~kg}$ in plant and 1.05 to $1.24 \mathrm{~kg}$ in ratoon. Highest number of millable canes (NMC) were observed in plots with healthy canes resulting in $94000 \mathrm{ha}^{-1}$ in plant and 73300 for ratoon which is significantly different from plots planted with YLD infected canes (66000 ha-1 for plant and $45000 \mathrm{ha}^{-1}$ in ratoon). NMC ranged between 73000 to $85000 \mathrm{ha}^{-1}$ in plant crop with different sett disinfection treatments which are statistically not significant. In ratoon the NMC are lower than plant crop with a range of $55800 \mathrm{ha}^{-1}$ to $65000 \mathrm{ha}^{-1}$ which are statistically not different from each other. In plant crop healthy cane planted plots recorded highest cane yields of $112.25 \mathrm{t}$

Table 2: Yield parameters with different sett disinfection treatments for the management of Yellow Leaf Disease (YLD)

\begin{tabular}{|c|c|c|c|c|c|c|c|c|}
\hline \multirow[t]{2}{*}{ Sl. No. } & \multicolumn{2}{|c|}{ Cane length (mt) } & \multicolumn{2}{|c|}{ Cane wt $\left(\mathrm{kg} \mathrm{cane}^{-1}\right)$} & \multicolumn{2}{|c|}{ NMC ('000 ha-1) } & \multicolumn{2}{|c|}{ Yield $\left(\mathrm{t} \mathrm{ha}^{-1}\right)$} \\
\hline & Plant & Ratoon & Plant & Ratoon & Plant & Ratoon & Plant & Ratoon \\
\hline $\mathrm{T}_{1}$ & $1.97(1.72)$ & $1.85(1.69)$ & $1.09(1.44)$ & $1.19(1.48)$ & 81.0 & 61.7 & 89.33 & 73.5 \\
\hline $\mathrm{T}_{2}$ & $1.68(1.68)$ & $1.83(1.68)$ & $1.15(1.46)$ & $1.19(1.48)$ & 79.0 & 61.7 & 90.37 & 73.0 \\
\hline $\mathrm{T}_{3}$ & $2.00(1.73)$ & $1.89(1.70)$ & $1.19(1.47)$ & $1.10(1.45)$ & 85.0 & 65.0 & 102.88 & 70.1 \\
\hline $\mathrm{T}_{4}$ & $1.88(1.70)$ & $1.90(1.70)$ & $0.96(1.40)$ & $1.07(1.44)$ & 84.0 & 60.8 & 81.12 & 65.3 \\
\hline $\mathrm{T}_{5}$ & $1.94(1.71)$ & $1.87(1.69)$ & $1.19(1.48)$ & $1.22(1.49)$ & 73.0 & 55.8 & 87.04 & 68.0 \\
\hline $\mathrm{T}_{6}$ & $1.93(1.71)$ & $1.89(1.70)$ & $1.32(1.52)$ & $1.05(1.43)$ & 84.0 & 61.7 & 112.25 & 65.6 \\
\hline $\mathrm{T}_{7}$ & $2.15(1.77)$ & $2.12(1.77)$ & $1.14(1.46)$ & $1.14(1.46)$ & 94.0 & 73.3 & 107.66 & 83.3 \\
\hline $\mathrm{T}_{8}$ & $1.88(1.70)$ & $1.85(1.69)$ & $1.22(1.49)$ & $1.24(1.50)$ & 82.0 & 60.8 & 101.83 & 75.9 \\
\hline $\mathrm{T}_{9}$ & $1.90(1.70)$ & $1.87(1.69)$ & $1.30(1.52)$ & $1.08(1.44)$ & 80.0 & 60.0 & 104.51 & 65.2 \\
\hline $\mathrm{T}_{10}$ & $1.77(1.66)$ & $1.76(1.66)$ & $1.04(1.43)$ & $1.17(1.47)$ & 66.0 & 45.0 & 68.68 & 52.5 \\
\hline $\mathrm{SEm} \pm$ & 0.037 & 0.028 & 0.040 & 0.030 & 6.690 & 4.438 & 14.024 & 5.917 \\
\hline $\mathrm{CD}(p=0.05)$ & NS & NS & NS & NS & NS & 13.289 & NS & NS \\
\hline
\end{tabular}


$\mathrm{ha}^{-1}$ compared to infected canes planted plots $68.68 \mathrm{tha}^{-1}$. All the plots with TSP sett treatments recorded $89.33,90.37$ and $102.88 \mathrm{t} \mathrm{ha}^{-1}$ in 5, 10 and $20 \%$ doses respectively which are all statistically at par. Similar results were observed in other sett treatments with yields ranging between 81.12 to 104.51 t ha ${ }^{-1}$ which is statistically not different. Reduced yields were recorded in ratoon crop compared to plant crop in all the ten experimental plots with highest mean yields recorded in healthy cane plots $\left(83.3 \mathrm{t} \mathrm{ha}^{-1}\right)$ followed by $\mathrm{NaCl}_{3} \%\left(75.9 \mathrm{t} \mathrm{ha}^{-1}\right)$ and TSP $5 \%\left(73.5 \mathrm{tha}^{-1}\right)$ which are statistically not significant with rest of the treatments with TSP $10 \%\left(73 \mathrm{tha}^{-1}\right)$, TSP $20 \%(70.1$ $\left.\mathrm{t} \mathrm{ha}^{-1}\right)$, sterile water $\left(65.3 \mathrm{tha}^{-1}\right)$, Ethanol $\left(68.0 \mathrm{tha}^{-1}\right)$, infected sap dip $\left(65.6 \mathrm{tha}^{-1}\right)$ and $\mathrm{NaCl} 6 \%\left(65.2 \mathrm{t} \mathrm{ha}^{-1}\right)$.

Results on the effect of the sett disinfection treatments on various other cane parameters viz., cane diameter, number of internodes and internode length was presented in Table 3. In healthy canes cane diameter was higher with $2.10 \mathrm{~cm}$ in plant and $2.26 \mathrm{~cm}$ in ratoon compared to plots with infected setts in both plant $(1.76 \mathrm{~cm})$ and ratoon $(2.16 \mathrm{~cm})$ crop which are statistically not significant. Similar results were observed in all other sett treatments with values ranged between 1.98 $\mathrm{cm}$ to $2.51 \mathrm{~cm}$ for plant crop and 2.08 to $2043 \mathrm{~cm}$ in ratoon crop. Similarly, number of internodes and internode length in different treatments did not showed any significant differences among them. The mean number of internodes varied between 24 to 28 in plant and 24 to 29 for ratoon crop. In plant crop the mean internode length was between $6.9 \mathrm{~cm}$ (infected canes) to $8.3 \mathrm{~cm}$ (heathy canes) where as it was between 6.6 and $7.8 \mathrm{~cm}$ in case of ratoon crop. In plant crop, the mean percent reduction of internode length was highest in infected canes (16.7\%) which is on par with Ethanol $70 \%$ treated setts followed by TSP 5\% (12.6\%) and $\mathrm{NaCl} 6 \%$ (11.8\%). $\mathrm{NaCl}$ $3 \%$ sett treatment resulted in least internode reduction per cent with $3.1 \%$ followed by TSP $10 \%(6.3 \%)$ and infected sap dip (7.2\%). Percent reduction of internode length is much higher in case of ratoon crop with $17.3 \%$ in ethanol treated setts followed by infected canes (14.8\%). The results revealed that the sett disinfection treatments did not have any effect on the cane factors viz., diameter, internode length and number and all the treatments are statistically not significant with each other including healthy and infected checks.

\subsection{Effect on sugarcane juice quality aspects}

Juice quality parameters were recorded in all the sett disinfection treatments in both plant and ratoon crops and the results were given in Table 4 . The results showed that the brix readings were not significant among the different treatments with the mean values ranging between $18.24(\mathrm{NaCl} 3 \%)$ to 19.60 (healthy canes) in plant crop and 17.18 (TSP 5\%) to 20.41 (healthy) in ratoon. Juice sucrose per cent (Pol\%) also showed similar trend for plant crop with mean values between 13.01 (infected canes) and 14.80 (healthy canes) with no statistical significance. But for ratoon crop Pol\% showed significant variation between healthy (20.21\%) and infected $(13.87 \%)$ cane plots which are also significantly different from other disinfection treatments. Whereas, all the sett treatments did not showed any significant variation between them with Pol\% values ranging from 15.21 to 18.49 . Similarly, Commercial Cane Sucrose (CCS) per cent was not significant in plant crop with values between 7.97 (infected canes) and 9.66 (healthy canes), while in case of ratoons significant differences was observed in percent CCS with healthy (15.10) and infected (13.39) canes. Results showed that percent CCS

\begin{tabular}{|c|c|c|c|c|c|c|c|c|}
\hline \multirow[t]{2}{*}{ Sl. No. } & \multicolumn{2}{|c|}{ Cane diameter $(\mathrm{cm})$} & \multicolumn{2}{|c|}{ No of internodes } & \multicolumn{2}{|c|}{ Internode length $(\mathrm{cm})$} & \multicolumn{2}{|c|}{ Percent reduction } \\
\hline & Plant & Ratoon & Plant & Ratoon & Plant & Ratoon & Plant & Ratoon \\
\hline $\mathrm{T}_{1}$ & $1.98(1.72)$ & $2.18(1.78)$ & 27 & 27 & $7.3(2.87)$ & $6.9(2.80)$ & 12.6 & 11.5 \\
\hline $\mathrm{T}_{2}$ & $2.51(1.87)$ & $2.29(1.81)$ & 24 & 26 & $7.8(2.96)$ & $7.3(2.86)$ & 6.3 & 6.6 \\
\hline $\mathrm{T}_{3}$ & $1.73(1.65)$ & $2.48(1.87)$ & 27 & 28 & $7.4(2.90)$ & $6.8(2.79)$ & 10.8 & 12.9 \\
\hline $\mathrm{T}_{4}$ & $2.10(1.75)$ & $2.18(1.78)$ & 26 & 26 & $7.3(2.90)$ & $7.3(2.88)$ & 11.5 & 6.5 \\
\hline $\mathrm{T}_{5}$ & $2.05(1.74)$ & $2.43(1.85)$ & 28 & 29 & $6.9(2.80)$ & $6.4(2.72)$ & 16.7 & 17.3 \\
\hline $\mathrm{T}_{6}$ & $2.02(1.73)$ & $2.42(1.85)$ & 25 & 28 & $7.7(2.95)$ & $6.9(2.80)$ & 7.2 & 12.1 \\
\hline $\mathrm{T}_{7}$ & $2.10(1.75)$ & $2.26(1.80)$ & 26 & 27 & $8.3(3.05)$ & $7.8(2.96)$ & 0.0 & 0.0 \\
\hline $\mathrm{T}_{8}$ & $2.12(1.76)$ & $2.08(1.75)$ & 24 & 24 & $8.0(3.01)$ & $7.6(2.93)$ & 3.1 & 2.5 \\
\hline $\mathrm{T}_{9}$ & $2.11(1.76)$ & $2.37(1.84)$ & 26 & 28 & $7.3(2.87)$ & $6.9(2.79)$ & 11.8 & 11.6 \\
\hline $\mathrm{T}_{10}$ & $1.76(1.66)$ & $2.16(1.78)$ & 26 & 27 & $6.9(2.81)$ & $6.6(2.76)$ & 16.7 & 14.8 \\
\hline $\mathrm{SEm} \pm$ & 0.049 & 0.045 & 1.532 & 2.131 & 0.116 & 0.110 & & \\
\hline $\mathrm{CD}(p=0.05)$ & NS & NS & NS & NS & NS & NS & & \\
\hline
\end{tabular}




\begin{tabular}{|c|c|c|c|c|c|c|c|c|}
\hline \multirow[t]{2}{*}{ Sl. No. } & \multicolumn{2}{|c|}{ Brix reading } & \multicolumn{2}{|c|}{ Pol \% } & \multicolumn{2}{|c|}{ CCS \% } & \multicolumn{2}{|c|}{ Purity } \\
\hline & Plant & Ratoon & Plant & Ratoon & Plant & Ratoon & Plant & Ratoon \\
\hline $\mathrm{T}_{1}$ & 19.10 & 17.18 & 13.74 & 17.58 & 8.70 & 13.31 & 72.88 & 89.89 \\
\hline $\mathrm{T}_{2}$ & 19.23 & 19.70 & 14.26 & 16.83 & 9.21 & 11.76 & 74.17 & 85.38 \\
\hline $\mathrm{T}_{3}$ & 18.92 & 17.81 & 14.10 & 15.21 & 9.13 & 10.63 & 74.52 & 84.43 \\
\hline $\mathrm{T}_{4}$ & 19.32 & 17.94 & 14.18 & 15.94 & 9.09 & 11.35 & 73.36 & 91.43 \\
\hline $\mathrm{T}_{5}$ & 18.60 & 19.42 & 13.40 & 18.49 & 8.49 & 13.59 & 72.01 & 90.51 \\
\hline $\mathrm{T}_{6}$ & 19.01 & 18.79 & 13.99 & 17.18 & 8.99 & 12.40 & 73.58 & 91.53 \\
\hline $\mathrm{T}_{7}$ & 19.60 & 20.41 & 14.80 & 20.21 & 9.66 & 15.10 & 78.57 & 90.98 \\
\hline $\mathrm{T}_{8}$ & 18.24 & 17.46 & 13.15 & 16.15 & 8.34 & 11.72 & 71.73 & 77.87 \\
\hline $\mathrm{T}_{9}$ & 19.03 & 18.15 & 14.35 & 16.28 & 9.36 & 11.65 & 75.45 & 89.98 \\
\hline $\mathrm{T}_{10}$ & 18.97 & 16.90 & 13.01 & 13.87 & 7.97 & 13.39 & 71.20 & 77.46 \\
\hline $\operatorname{SEm} \pm$ & 0.528 & 1.043 & 0.629 & 0.741 & 0.088 & 0.091 & 1.535 & 2.660 \\
\hline $\mathrm{CD}(p=0.05)$ & NS & NS & NS & 2.218 & NS & 0.274 & NS & 7.965 \\
\hline
\end{tabular}

also varied among different treatments for ratoon crop but the healthy canes proved to be superior with highest CCS\%. There is not much variation is observed in case of juice purity per cent for plant crop, where as in ratoon crop all sett treatments significantly differed from infected canes $(77.46 \%)$ except for $\mathrm{NaCl}_{3} \%$ (77.87\%) which is statistically on par with infected canes. Thus from the present study it can be inferred that the sett disinfection chemicals did not had any role in determining the juice quality aspects. Whereas healthy canes showed higher juice quality values, especially in ratoon, emphasizing the role of healthy planting material for the effective management of YLD in field conditions.

\subsection{Confirmation of sett disinfection by DAS-ELISA}

Randomly selected sugarcane plants from the different sett disinfection treatment plot from all the three replications was screened using DAS-ELISA at the end of ratoon crop of 201516 for the detection of SCYLV in the samples. All the samples were tested positive for the virus including plots planted with healthy canes in one replication (Figure 1) showing varied colour change in the microtiter plate. This confirms the present study that the sett disinfection chemicals were not effective for eliminating the virus from the infected setts of sugarcane.

\subsection{Correlation of SPAD chlorophyll values with YLD} incidence

Leaf chlorophyll content was measured in six different varieties showing YLD symptoms of different grades using SPAD chlorophyll meter and the results are presented in Figure 2. The mean SPAD Chlorophyll meter readings (SCMR) measured in the three visible dew lap leaves (VDL) varied with varying YLD grades. Variety 2001A 63 recorded mean SCMR value of 26.7 in leaves with disease grade of 1 and in leaves with grade 2 the value was 25.2. In leaves with grade 3, 4 and 5 mean SCMR values of $19.8,17.1$ and 14.1 were recorded

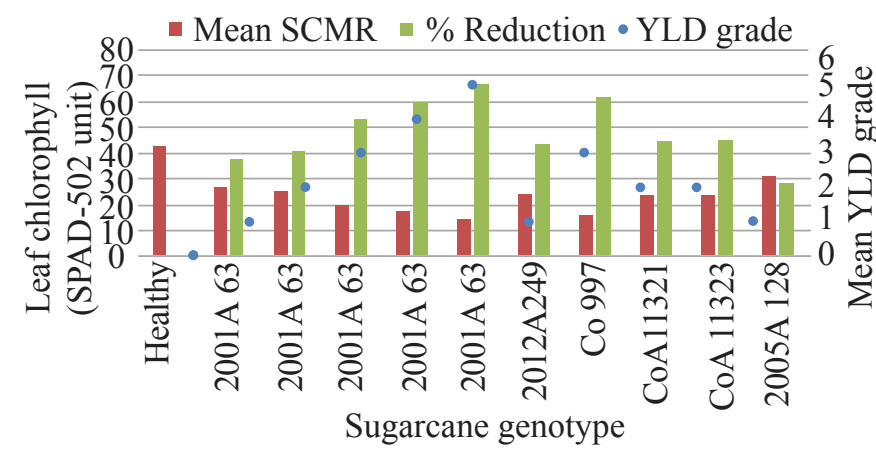

Figure 1: Impact of yellow leaf on leaf chlorophyll content in six sugarcane genotypes showing varied disease grades

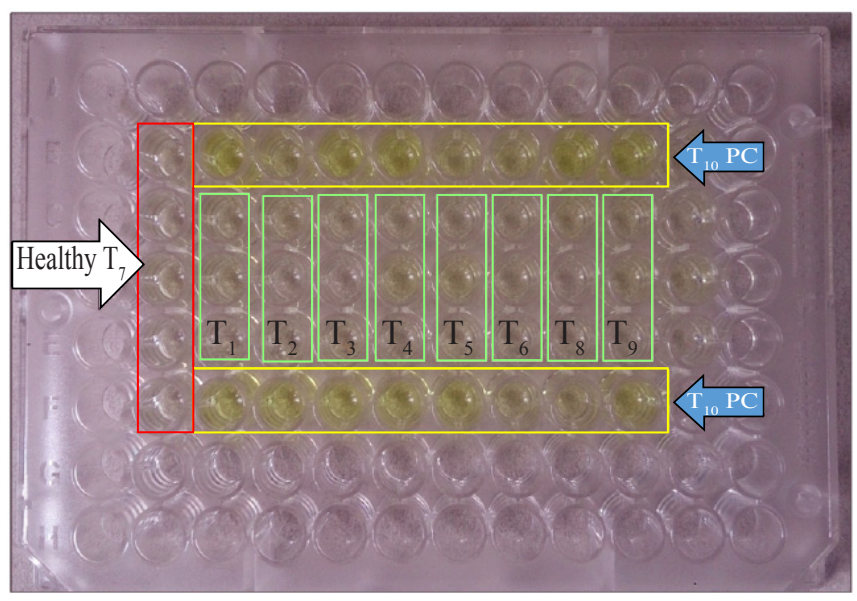

Figure 2: DAS-ELISA confirmation of the effect of sett disinfection treatments for the management of yellow leaf disease (YLD) of sugarcane 
respectively. Thus, the mean SCMR values decreased with increasing YLD grade. Variety 2012A 249 with YLD grade of 1 showed a mean SCR value was 24.1 and variety 2005A 128 with the same disease grade recorded 30.8 mean SCMR value. Whereas, varieties CoA 11321 and CoA11323 with mean grade of 2 recorded SCMR values of 23.6 and 23.5 respectively. Variety Co 997 having disease grade of 3 recorded 16.1 mean SCMR value. Healthy asymptomatic plants recorded higher mean SCMR value of 42.7. Similarly, a clear reduction of SCMR values in infected plants was observed in the range of $28 \%$ to $67 \%$ varying with varying disease grade and also with genotype. Highest reduction of $67 \%$ observed in variety 2001A 63 with grade 5 followed by $62.2 \%$ in Co 997 showing grade 3 symptoms.

Meinzer and Zhu (1998) reported that photosynthetic rates in YLD symptomatic plants were decreased due to massive accumulation of glucan grains in the bundle-sheath chloroplasts leading to lower chlorophyll, $\mathrm{P}$ and $\mathrm{N}$ content in leaves. Several studies (Lehrer et al., 2001 and Comstock et al., 1998) reported that SCYLV infection slows down the export of assimilates from the source leaves to the sink resulting in assimilates backing up in the source leaves, eventually inducing degradation of chlorophyll and chloroplasts resulting in leaf yellowing. Brix readings for carbohydrate content of juice of YLD symptomatic plants are two to three times higher in leaf midribs compared to healthy plants. Further, the physiology of the infected plants become altered and that the infected leaves exhibit a higher carbohydrate level, a lowered chlorophyll $\mathrm{a} / \mathrm{b}$ ratio and a smaller photosynthetic capacity. Carbohydrate accumulation in leaves may cause visible symptoms in SCYLV infected plants which leads to reduce Rubisco synthesis thus leading to chlorophyll breakdown (Izaguirre-Mayoral et al., 2002; Krapp et al., 1991; Krapp and Stitt 1995). Viswanathan et al. (2014) reported significant reduction in photosynthetic parameters in four cultivars with different disease grades and a gradual decline of chlorophyll from grade 0 to 4 was observed. Present study confirms the earlier reports as the SCMR readings are negatively correlated with the YLD grade and as the disease grade increases there was a corresponding reduction in the leaf chlorophyll content as evident by the lower SCMR values.

\section{Conclusion}

There is no significant effect of sett disinfection chemicals on YLD incidence, confirmed by DAS-ELISA, as well as on yield, cane growth and juice quality parameters of sugarcane in both plant and ratoon crops. Per cent reduction of chlorophyll content increased with disease grade in 2001A 63, a susceptible genotype, and varied with variety. Thus, healthy canes proved as the best management option for YLD with reduced disease incidence resulting in increased NMC and cane yields.

\section{Acknowledgement}

Authors are greatful to Dr. Raja Reddy, Director of Extension, ANGRAU and Associate Director of Research, RARS, Anakapalle for providing necessary financial and technical support during the period of study.

\section{References}

Comstock, J.C., Irey, M.S., Lockhart, B.E.L., Wang, Z.K., 1998. Incidence of yellow leaf syndrome in CP cultivars based on polymerase chain reaction and serological techniques. Sugar Cane 4, 21-24.

Cordoba-Selles, M.C., Garcia-Randez, A., Alfrado-Fernandez, A., Jorda-Gutierrez, C., 2007. Seed transmission of Pepino mosaic virus and efficacy of tomato seed disinfection treatments. Plant Disease 91, 1250-1254.

Izaguirre-Mayoral, M.L., Carballo, O., Alceste, C., Romano, M., Nass, H.A., 2002. Physiological performance of asymptomatic and yellow leaf syndrome-affected sugarcane in Venezuela. Journal of Phytopathology $150,13-19$.

Krapp, A., Quick, W.P., Stitt, M., 1991. Ribulose-1, 5-bisphosphate carboxylase-oxygenase, other photosynthetic enzymes and chlorophyll decrease when glucose is supplied to mature spinach leaves via the transpiration stream. Planta 186, 58-69.

Krapp, A., Stitt, M., 1995. An evaluation of direct and indirect mechanisms for the "sink-regulation" of photosynthesis in spinach: changes in gas exchange, carbohydrates, metabolites, enzyme activities and steady-state transcript levels after cold girdling source leaves. Planta 195, 313-323.

Lehrer, A.T., Schenck, S., Fitch, M.M.M., Moore, P.H., Komor, E., 2001. Distribution and transmission of sugarcane yellow leaf virus (SCYLV) in Hawaii and its elimination from seed cane. In: Proceedings of $24^{\text {th }}$ International Society of Sugar Cane Technologists Congress, Brisbane 2001. The Australian Society of Sugar Cane Technologists, Mackay, 439-443.

Lewandowski, D.J., Hayes, A.J., 2010. Surprizing results from a search for effective disinfectants for Tobacco mosaic virus-contaminated tools. Plant Disease 94(5), 542-550.

Meade, G.P., Chen, J.C.P., 1971. Sugarcane hand book $10^{\text {th }}$ Edition, John wiley and sons. New York.

Meinzer, F.C., Zhu, J., 1998. Nitrogen stress reduces the efficiency of the $\mathrm{C}_{4} \mathrm{CO}_{2}$ concentration system, and therefore quantum yields in Saccharum (sugarcane) species. Journal of Experimental Botany 49, 1227-1234. 
Rajkumar, N., Suresh, M., Prasada Rao, K., Ankaiah, R., 2012. Current status of Sugarcane diseases in Andhra pradesh. Proceedings of AICRP on Sugarcane group meeting, $25^{\text {th }}-26^{\text {th }}$ October, 2013. 97-98.

Rao, G.P., Gaur, R.K., Singh, M., Viswanathan, R., Chandrasena, G., Dharamwardhaanhe, N.M.N.N., 2001. Occurrence of sugarcane yellow leaf virus in India and Srilanka. Proceedings of International Society of Sugar Cane Technologists 24, 469-470.

Schenck, S., 1997. Pathology report 67. Hawaii Agriculture Research Centre, 4.

Schenck, S., Hu, J.S., Lockhart, B.E.L., 1997. Use of a tissue blot immunoassay to determine the distribution of sugarcane yellow leaf virus in Hawaii. Sugar Cane 4, 5-8.

Turner, F.T., Jund, M.F., 1991. Chlorophyll meter to predict nitrogen top-dress requirement for semi dwarf rice.
Agronomy Journal 83, 926-928.

Vega, I., Scagliusi, S.M.M., Ulian, E.C., 1997. Sugarcane yellow leaf disease in Brazil: Evidence of association with a lute virus. Plant Disease 81, 21-26.

Viswanathan, R., Chinnaraja, C., Malathi, P., Gomathi, R., Rakkiyappan, P., Neelamathi, D., Ravichandran, V., 2014. Impact of Sugarcane Yellow Leaf Virus (ScYLV) infection on physiological efficiency and growth parameters of sugarcane under tropical climatic conditions in India. Acta Physiologiae Plantarum 36, 1805-1822.

Viswanathan, R., Padmanaban, P., Mohanraj, D., Ramesh Sundar, A., Premachandran, M.N., 1999. Suspected yellow leaf syndrome in sugarcane. Sugarcane Breeding Institute Newsletter 18(3), 2-3. 